\title{
Human resource competencies, supply chain management, and financial performance
}

\author{
Candra Wahyu Hidayat ${ }^{\mathrm{a}}$, Sulistyo ${ }^{\mathrm{a}^{*}}$, Sri Wilujeng ${ }^{\mathrm{a}}$, Yustina Chrismardani ${ }^{\mathrm{b}}$ and Wahab $^{\mathrm{c}}$
}

${ }^{a}$ Faculty of Economics and Business, Universitas PGRI Kanjuruhan Malang, Indonesia

${ }^{b}$ Faculty of Economics and Business, Universitas Trunojoyo Madura, Indonesia

${ }^{c}$ FAST School of Management, National University of Computer and Emerging Sciences, Islamabad, Pakistan

A B S T R A C T

\section{Article history:}

Received October 1, 2021

Received in revised format

October 25, 2021

Accepted December 62021

Available online

December 102021

Keywords:

Human resource competencies

Supply chain management

Financial performance

SMES

\begin{abstract}
This research was conducted on SMEs in Indonesia, by prioritizing the local wisdom of the Indonesian nation as a tropical, agrarian country, with SMEs owners who process fruits and vegetables into snacks as respondents. The study involved 243 respondents, to determine the partial and simultaneous influence of human resource competences and supply chain management on financial performance. The reason for doing this research is because some of the research that has been done by previous researchers still discusses this on corporate and not on SMEs. However, market conditions have changed. SMEs need to be managed professionally, by minimizing expenses to maximize revenue, taking into account risk, resource capabilities, in flexible ways as well as low-cost. The results showed that there was a significant influence on the financial performance of SMEs with the presence of human resource competences and supply chain management either partially or simultaneously.
\end{abstract}

\section{Introduction}

SMEs are traditional family businesses for their business activities. Relationships with suppliers are one example, which requires trust and familial communication, considering that SMEs do not have the ability to provide guarantees for their transactions (Menon, 2012). Good relationships with suppliers are one of the topics of supply chain management that provide long-term benefits for SMEs (Shpak et al., 2017). SMEs with good supply chain management, apart from being able to reduce operational costs, also provide added value for consumers, such as improving delivery quality and having a competitive advantage (Kozma, 2017).

One of the supply chain management lies in the competence of human resources. In the context of supply chain, human resource competence focuses on the ability of someone who is responsible for supply chain management (Swart, Hall, \& Chen, 2014). A person's ability in supply chain management is actually general and does not require special competencies (Koulikoff \& Harrison, 2010), but it is important to establish flexible job descriptions, job evaluations and rewards (Menon, 2012), and the importance of teamwork, leadership, negotiation, and relationship management (Menon, 2012).

The role of human resources in supply chain management must be supported by top management (Bharthvajan, 2014), besides that employees at all levels must be sensitive to being oriented towards running the right supply chain (Asnordin, Sundram, $\&$ Noranee, 2020). When all members of the organization understand all transaction systems in the organization oriented to customers, suppliers, governments and other related parties, and always try to harmonize work processes, then human resources are said to have acted as enablers to build the organization into a learning organization, and see the organization as a system that must be maintained for its sustainability (Barnes \& Liao, 2012). Supply chain management is part of making it happen (Menon, 2012).

* Corresponding author

E-mail address: sulistyo@unikama.ac.id (Sulistyo)

(c) 2022 Growing Science Ltd. All rights reserved.

doi: $10.5267 /$ j.uscm.2021.12.004 
Several studies discuss the role of supply chain management in achieving financial performance (Wahdan \& Emam, 2017; Jin, Jeong, \& Kim, 2017; Lee, 2021; Baabaker et al., 2021); and focus on accounting management (Almatarneh, Jarah, \& Al Jarrah, 2021) and focus on efficiency and profitability (Riyadi, Nugroho, \& Arif, 2021). In this study, it is attempted to include the competence of human resources along with the role of supply chain management on financial performance. Most of the research is done in companies and almost none is on SMEs, and research is currently underway. The consideration is that the current management of SMEs can no longer be done conventionally and modestly. Competition is getting tougher, every SMEs must try to find opportunities despite their limitations. Human resource competence can no longer be ignored, good management is needed to support business sustainability, supply chain management needs to be followed up properly, to provide opportunities for SMEs to establish good relations with all parties related to their business sector, thus making the business sustainable.

\section{Literature Review}

\subsection{Human Resource Competencies}

Competence is an individual characteristic with effective reference criteria or superior performance in a job or situation (Barnes \& Liao, 2012). This means that competence is part of the individual basis and lasts a long time or is a personality and behavior when on duty (Menon, 2012). Competence is one of the important concepts for businesses to achieve success, and there are two competencies, individual competencies and organizational competencies (Kasim, 2015). So that it can be concluded that competence is the ability to apply knowledge, skills, behavior and personality to perform tasks for both individuals and organizations to achieve superior work performance. In the context of human resource management, individual competence is considered to consist of skills and knowledge related to individual performance and performance at the team level, which is a person's competence to interact with other team members (Barnes \& Liao, 2012). Currently, what is considered competent is the ability to communicate, work together, willingness to create a collaborative and learning environment. Along with developments, such as the presence of globalization, competence must include process capabilities that improve organizational performance.

\subsection{Supply Chain Management}

Lately, supply chain management has become the main discussion as a holistic approach to increase efficiency and gain competitive advantage (Darmawan, Maulida, \& Nasito, 2021). Supply chain management is defined as the management of various interrelated areas involved in the production, procurement, processing and marketing processes (Mentzer, Myers, \& Stank, 2006). The term supply chain management is often used for strategic issues (Min, Zacharia, \& Smith, 2019), which is the strategic and systematic coordination of all business functions for the purpose of improving long-term performance. In essence, supply chain management is an interconnected work, it cannot exist if it is done separately (Lambert \& Enz, 2017). Today, globalization brings access to consumers in new ways around the world, thus requiring an understanding of different markets, including potential partners, risks and regulations (Mentzer, Myers, \& Stank, 2006). Without supply chain management, products will not be able to efficiently reach markets throughout the world, because with supply chain management products can reach as many markets as possible, by crossing national boundaries (Vidrova, 2019). Supply chain management is a transformation process that aims to increase efficiency, with effective integration of suppliers, manufacturers and distributors starting from the procurement of materials, transformation of materials into finished products, and distribution of products to consumers in the right quantities, to the right locations, and at the right time to meet the required level of service at minimal cost (Farahani, Meier, \& Wilke, 2015).

\subsection{Financial Performance}

Several studies have shown that supply chain management is able to make a positive contribution to financial performance, by looking at the value of short-term and long-term solvency, assessing the position and trend of liquidity and profitability, knowing the efficiency of financial operations, and by analyzing the factors that determine the behavior of liquidity and profitability. (Wahdan \& Emam, 2017). Supply chain management is able to integrate production plans and schedules (Chang et al., 2016), is able to consistently improve the company's financial performance (Autry, Rose, \& Bell, 2014), and deeper integration with suppliers, and customers can create strategic competitive value. for the company, increasing innovation, making products last longer in the maturity phase in the product life cycle which provides more long-term benefits for the company (Chang et al., 2016). Supply chain management is identical to financial performance as measured by involving Economic Value Added (EVA), by reducing capital expenditures to maximize revenue (Jin, Jeong, \& Kim, 2017).

\section{Hypotheses Development}

Research which states that human resource competence is important in supporting supply chain management is proposed by Barnes and Liao (2021), Asnordin et al. (2020), Bharthvajan (2014), human resource competence positively supports 
financial performance by Kasim (2015) and supply chain management contributes to financial performance as stated in research conducted by Wahdan and Emam, (2017), Lee (2021), Jin, Jeong, \& Kim (2017). So in this study the hypothesis is:

H1: Partially there is a positive and significant relationship between human resources competencies and financial performance.

H2: Partially there is a positive and significant relationship between supply chain management and financial performance.

H3: Simultaneously there is a positive and significant relationship between human resources competencies and supply chain management toward financial performance.

\section{Methodology}

The research was conducted quantitatively, by testing the hypothesis to prove its truth. The data was collected using a questionnaire submitted online to 280 SMEs owners who produce snacks from fruits and vegetables in Indonesia. Indonesia, as a tropical country, is very abundant in agricultural and plantation products and most of the people work as entrepreneurs in this sector. A total of 243 questionnaires managed to get a response and were declared eligible to be research data.

Analysis with hypothesis test and classical assumption test with software Minitab 18. The human resource competencies variable is represented by seven statements based on Kasim's research (2015), supply chain management consists of nine statements from research completed by Darmawan, Maulida, \& Nasito (2021), and three statements representing financial performance variables taken from Wahdan \& Emam (2017).

\section{Results}

Partial parameter significance test is a test to calculate the influence of an independent variable on the dependent variable individually. By using a significance level of 5\%, we get the T table, is $\mathrm{T}(\alpha / 2 ; \mathrm{n}-\mathrm{k}-1)$ or $\mathrm{T}(0.025: 240)=0.000104$. With the value of $\mathrm{n}$ is the amount of data and $\mathrm{k}$ is the number of independent variables. Because Tvalue $>$ Ttable $=4.41>0.000104$ (for human resources competence) and $2.35>0,000104$ (for supply chain management), so H1 and H2 are accepted. According to the data in table 1 below:

Table 1

Regression Analysis

\begin{tabular}{llllll}
\hline Predictor & Coef & SE Coef & T & P & VIF \\
\hline Constant & 13.706 & 6.530 & 2.10 & 0.045 & \\
X1 (Human Resource Competences) & 0.7025 & 0.1592 & 4.41 & 0.000 & 1.090 \\
X2 (Supply Chain Management) & 0.5327 & 0.2263 & 2.35 & 0.026 & 1.090 \\
\hline
\end{tabular}

From the results of data processing using Minitab software, obtained a linear regression equation that is:

$\mathrm{Y}($ Financial Performance $)=13.7+0.702$ X1 (Human Resources Competences $)+0.533$ X2 (Supply Chain Management)

Explained that under normal circumstances, human resource competences will contribute $70 \%$ to financial performance and $53 \%$ provided by supply chain management in supporting financial performance.

Table 2

Analysis of Variance

\begin{tabular}{|c|c|c|c|c|c|}
\hline Source & DF & $\mathrm{SS}$ & MS & $\mathrm{F}$ & $\mathrm{P}$ \\
\hline Regression & 2 & 1083.22 & 541.61 & 16.90 & 0.000 \\
\hline Residual Error & 240 & 865.48 & 32.05 & & \\
\hline Total & 242 & 1948.70 & & & \\
\hline
\end{tabular}

Simultaneous support provided by human resource competences and supply chain management, seen from the calculated Fvalue (Table 2). Fvalue obtained is 16.90 . With a significance level of $5 \%$, Ftable is obtained: $F(\alpha ; k ; n-k)$ or $F(0.025:)=$ 0.000104 . Where the value of $\mathrm{n}$ is the number of data and $\mathrm{k}$ is the number of independent variables. Because Fvalue $>$ Ftable $=>16.90>0.000104$ so $\mathrm{H} 3$ is accepted. The coefficient of determination or Rsquare obtained is 0.556 meaning the ability of the independent variable to explain the variance of the dependent variable is $55.6 \%$ (table 3 ).

Table 3

Coefficient of Determination

\begin{tabular}{lll}
\hline $\mathrm{S}$ & $\mathrm{R}-\mathrm{Sq}$ & $\mathrm{R}-\mathrm{Sq}(\mathrm{adj})$ \\
\hline 5.66171 & $55.6 \%$ & $52.3 \%$ \\
\hline
\end{tabular}


Continued on the classical assumption test of the residuals. At this stage the residual test is shown in the regression processing with all predictors being the predictor variables of human resource competences and supply chain management. The goal is to ensure the truth of the hypothesis test. Classical assumption test is shown visually as follows:

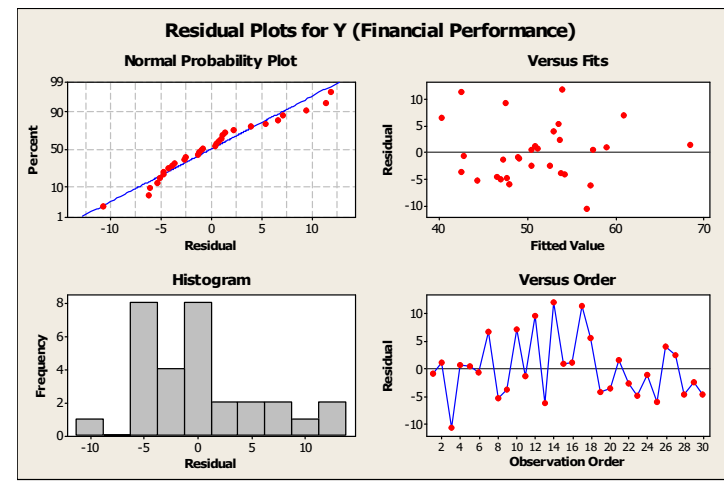

Fig. 1. Residual Plots

Residual test with normal distribution can be seen in the normal probability plot image. In the figure, it appears that the residual points follow the normal line so that it can be concluded that the residuals are normally distributed. Identical residual test is shown in figure versus fits. In the figure, it can be seen that the residual points do not form a certain pattern so that it can be concluded that the residuals do not occur heteroscedasticity. The independent residual test is shown by the figure versus order. In the figure, it can be seen that the residual points do not show a certain pattern and appear random, so it can be concluded that the residuals are independent.

\section{Discussion and Conclusion}

The results of the study prove that human resource competences and supply chain management are also important to be applied in SMEs. If Kasim (2015); Darmawan, Maulida, \& Nasito (2021), and Wahdan \& Emam (2017), explain the existence of these variables in corporate in supporting financial performance, in this study applied to SMEs and the results show the role of these variables is equally important. Indeed, it all depends on SMEs owners according to research (Bharthvajan, 2014), and agrees that financial performance is influenced by supply chain management (Wahdan \& Emam, 2017), and this situation must be understood, and implemented by all members of SMEs (Asnordin, Sundram, \& Noranee, 2020), which means that human resource competencies are also needed. Human resource competencies are able to create good supply chain management so that SMEs can operate effectively and efficiently for a sustainable business and ultimately achieve optimal financial performance.

\section{References}

Almatarneh, Z., Jarah, B., \& Jarrah, M. (2022). The role of management accounting in the development of supply chain performance in logistics manufacturing companies. Uncertain Supply Chain Management, 10(1), 13-18.

Asnordin, N. A., Sundram, V., \& Noranee, S. (2020). The Influence of Professional Human Resource and Firm Infrastructure towards Supply Chain Performance. International Journal of Academic Research in Business \& Social Sciences, 718732 .

Autry, C., Rose, W., \& Bell, J. (2014). A Logistic Stategy Taxonomy. Journal of Business Logistics, 275-276.

Baabaker, L. M., Ibrahim, N., Saadallah, H., \& Juma, M. (2021). The Impact of Supply Chain Strategy on the Financial Performance: A Case Study of A Manufacturing Company at Khartoum State. The Arab Journal of Scientific Research, 5(5) 39-56.

Barnes, J., \& Liao, Y. (2012). The effect of individual, network, and collaborative competencies on the supply chain management system. International Journal of Production Economics, 140(2), 888-899.

Bharthvajan, R. (2014). Human resource management and supply chain management intersection. International Journal of Innovative Research in Science, Engineering and Technology, 3(3), 10163-10167.

Chang, W., Ellinger, A. E., Kim, K. K., \& Franke, G. R. (2016). Supply chain integration and firm financial performance: A meta-analysis of positional advantage mediation and moderating factors. European Management Journal, 34(3), 282295.

Darmawan, B. A., Maulida, R., \& Nasito, M. (2021). Supply Chain Performance of SMEs: The Role of Triple-A Strategy. Kinerja, 91-102.

Farahani, P., Meier, C., \& Wilke, J. (2015). A Vision on A Digital Supply Chain Management. The Business Transformation Journal, 360(13), 1-15.

Jin, S. H., Jeong, S. J., \& Kim, K. S. (2017). A linkage model of supply chain operation and financial performance for economic sustainability of firm. Sustainability, $9(1), 139$. 
Kasim, E. Y. (2015). Effect of government accountants competency and implementation of internal control to the quality of government financial reporting. International Journal of Business, Economics and Law, 8(1), 97-105.

Koulikoff-Souviron, M., \& Harrison, A. (2010). Evolving HR practices in a strategic intra-firm supply chain. Human resource management, 49(5), 913-938.

Kozma, T. (2017). Cooperation in the supply chain network. In Forum Scientiae Oeconomia (Vol. 5, No. 3, pp. 45-58). Wydawnictwo Naukowe Akademii WSB.

Lambert, D. M., \& Enz, M. G. (2017). Issues in supply chain management: Progress and potential. Industrial Marketing Management, 62, 1-16.

Lee, R. (2021). The Effect of Supply Chain Management Strategy on Operational and Financial Performance. Sustainability, $1-13$.

Menon, S. T. (2012). Human resource practices, supply chain performance and wellbeing. International Journal of Manpower, 33(7), 769-785.

Mentzer, J. T., Myers, M., \& Stank, T. (2006). Handbook of global supply chain management. California: SAGE Publications.

Min, S., Zacharia, Z. G., \& Smith, C. D. (2019). Defining supply chain management: in the past, present, and future. Journal of Business Logistics, 40(1), 44-55.

Riyadi, S., Nugroho, M., \& Arif, D. (2021). The effect of supply network and management control system on the efficiency and profitability of manufacturing companies. Uncertain Supply Chain Management, 9(4), 963-972.

Shpak, N., Satalkina, L., Sroka, W., \& Hittmar, S. (2017). The social direction of enterprises' innovation activity. Polish Journal of Management Studies, 187-201.

Swart, W., Hall, C., \& Chen, H. (2014). Human Performance in Supply Chain Management. Supply Chain Forum. An International Journal, 13(2), 10-20.

Vidrova, Z. (2019). Supply chain management in the aspect of globalization. Globalization and its Socio-Economic COnsequences, 74, 1-10.

Wahdan, M. A., \& Emam, M. A. (2017). The impact of supply chain management on financial performance and responsibility accounting: Agribusiness case from Egypt. Accounting and Finance Research, 6(2), 136-149. 
(C) 2022 by the authors; licensee Growing Science, Canada. This is an open access article distributed under the terms and conditions of the Creative Commons Attribution (CCBY) license (http://creativecommons.org/licenses/by/4.0/). 